\title{
The Effect of Rice Subsidy on The Expenditure of Public Family Consumption And Welfare of Poor Households
}

\author{
Renny Maisyarah \\ Student Postgraduate Faculty Economi \\ Universitas Andalas Padang, West of Sumatera \\ Lecture Universitas Pembangunan Panca Budi \\ North of Sumatera \\ Rennymaisyarah@ymail.com \\ Sofyardi \\ Universitas Andalas, Padang, West of Sumatera \\ Sofyardi123@yahoo.co.id
}

\begin{abstract}
The aim of this study is to find out an influence of rice subsidy on the consumption expenditure of poor families in North Sumatera Province, so that there is an impact on the welfare of poor families in North Sumatra Province, and also the influence of rice subsidy on family welfare of poor families in Province North Sumatra through consumption expenditure. In the research use explanatory survey which is in the form of expost facto where is the research of series of variable-free variables have occurred, when the researcher started to observe the dependent variable. The type of data in this study is the primary data in the form of questionnaires distributed to the respondents. The population in this research is the number of recipients of rice subsidy in North Sumatera Province from 33 districts/cities in 2015 as many as 746,220 households. The sample in this research are 5 (five) biggest rice subsidy areas, among others; Deli Serdang District, Langkat Regency, Medan City, Simalungun Regency, and Asahan Regency. The method of analysis used in this research is Structural Equation Modeling (SEM).
\end{abstract}

Keywords -Government Policy, Subsidy Program, Poverty.

\section{INTRODUCTION}

Poverty is the inability to meet basic needs such as food, clothing, shelter, education, and health. Poverty can be caused by the scarcity of basic needs fulfillment, or the difficulty of access to education and employment. According to the Central Bureau of Statistics (BPS), poverty is the condition of a person who can only meet the needs of eating less than 2100 calories per capita per day.

The poor in North Sumatera Province in 2013 reached 1,390.80 thousand people. In 2014 it fell to $1,360.60$ thousand people and again increased significantly to $1,508.14$ thousand inhabitants. On average from 2013-2015, the number of poor people in North Sumatera Province reaches 1,419.85 thousand inhabitants. These figures are the highest in comparison with other provinces on the island of Sumatra.

The results showed that the increase of prosperity through rice subsidy program is greater than the subsidy in the form of sugar and cooking oil. "To obtain a level of well-being, the demand system model using the Linear Approximation Almost Ideal Demand System (LA / AIDS) model, applied to SUSENAS data 2007 and 2008, the world food price fluctuations that occurred due to competition for food and energy, poor households have difficulty in adjusting food prices consumed. In anticipation, the government should conduct a market intervention in the form of subsidies that are packed in various programs, one of which is the Raice subsidy program.

According to Tabor, Steven R and Sawit[1], food aid can solve some of the nutritional problems of poor families. In addition to direct benefits, the Raice subsidy program also provides indirect benefits such as job creation, health, and education costs, and contributes to price stabilization. Anak Bangsa Peduli [2], reported the presence of resource persons who thought that Rice subsidy program was beneficial because it created employment (labor-intensive) for other parties such as freight and coolie. LP3ES [3], reports that although small, the transfer of income from the Rice subsidy program can save money, among others, for health and education costs. 
Furthermore, wrote that Rice subsidy program could maintain the stability of rice prices. The results of field studies show that provincial, district and subdistrict stakeholders have diverse assessments of the benefits of the Rice subsidy program for poor households. Some stakeholders rated the Rice subsidy program as helping poor people in food fulfillment, and some considered the Rice subsidy program as a poor educational program for making poor households spoiled. Beneficiary households assess Rice subsidy program as beneficial although the amount of rice is found less and the quality is sometimes poor

\section{LITERATURE REVIEW}

According to the Central Bureau of Statistics (2010), poverty is the inability to meet minimum standards of basic needs that include both food and non-eating needs. Compare the rate of consumption of the population with the poverty line or the number of rupiahs for monthly consumption. While Bappenas (2004) defines poverty as a condition in which a person or group of men and women are unable to fulfill their basic rights to maintain and develop a dignified life. The basic rights of the village community include the fulfillment of food, health, education, employment, housing, clean water, land, natural resources and the environment, security from the treatment or threat of violence and the right to participate in socio-political activities, both for women and for men.

In other countries the programs that have been implemented in poverty reduction are poverty assistance, or assisting directly with the poor, this approach has been part of the approach of European society since the Middle Ages; assistance to the individual, ie the efforts undertaken to change the situation of the poor on the basis of the individual, including law, education, social work, job-seekers; preparation for the weak, ie, the efforts made by providing assistance to people categorized as poor, such as parents or individuals with disabilities, or circumstances that make the poor, such as the need for food and health (The World Bank, 2007).

Stiglitz[4], states that to define welfare, the multidimensional formulation should be used. These dimensions include material living standards (income, consumption, and wealth), health, education, individual activities including work, political voice, and governance, social relationships and kinship, the environment (present and future conditions), both economic and physical. All of these dimensions show the quality of life of the people and to measure it requires objective and subjective data.
The formulation of the welfare concept by the Central Bureau of Statistics (BPS) and the National Family Planning Coordinating Board (BKKBN) says that the families are supposed to be in the balance if they meet the following criteria.

a) Families that can meet the needs of its members whether clothing, food, housing, social and religious needs;

b) Families that have a balance between family income and the number of family members; and

c) Families who can meet the health needs of family members, live together with the surrounding community, worship in addition to fulfilled basic needs.

The law of demand reads "When the price rises than a number of goods required decreases vice versa when the price drops, then some goods demanded increases." Based on the law of demand above, when the price of a good or service rises then the quantity of demand for goods or services will fall. The decrease in the quantity of goods or services is due to two reasons:

a) Substitution effect

According to Pyndick [5], when the price of a good or service rises, many households will switch, in whole or in part, to other similar goods or services. So the amount purchased from goods or services whose price has gone up will be less.

b) income effects

States when the price of a good or service rises (if the income received by the customer remains/does not change), a consumer will feel poorer than before. This case is because they assume that their income is decreasing / slightly, so they will limit the consumption of goods or services.

The effect of price changes on demand as described above can be illustrated in Figure 2.1 In the figure it appears that the budget line was originally an RS where there were two food items and clothing. Here, the consumer maximizes utility by choosing a market basket at $\mathrm{A}$, thus obtaining service levels from the $\mathrm{U}_{1}$ indifference curve. 

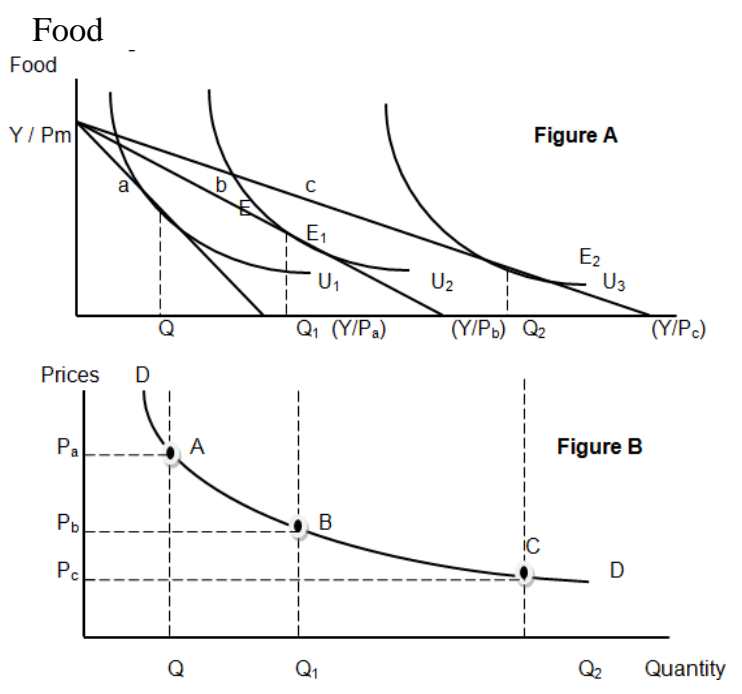

Figure 2.1: Derivation of Clothes Demand Curve

If the food price falls causing the budget line to circle outside the RT line. The consumer now chooses a market basket on B on the U2 indifference curve. Since the B market basket has been chosen even if A market basket is actually also selectable, it can be known with the preferences revealed that B is preferred over A. The fall in food prices has income and substitution effects. Consumers initially exist in A on the RS budget line. When food prices fall, consumption increases by F1F2 while consumers move to the substitution B effect, F1E (associated with movement from $A$ to $D$ ) changes the relative price of food and clothing but keeps real income (satisfaction) constant. EF2 income effect (associated with movement from D to B) keeps the price relatively stable but increases in purchasing power. Food is a normal item because the EF2 income effect is positive.

Based on the indifference curve and budget line with the substitution effect behavior and income effect above can be established the demand curve. Suppose the income of consumers remains $\mathrm{Y}$ and the price of food is $\mathrm{Pm}$ and the price of clothing is $\mathrm{Pa}$. Thus at the beginning the line a represents the budget line of consumer spending. Line a alludes to the same satisfaction curve $\mathrm{U} 1$ at point $E$. Therefore the amount of clothing consumed is Q unit. Furthermore, suppose the income and the price of food do not change, but the price of clothing decreases and now has become $\mathrm{Pb}$. With this change the expenditure budget line is now indicated by line $\mathrm{b}$. He alluded to the same U2 satisfaction curve at point E1. This balance illustrates that the consumed clothing has risen to Q1 units. Suppose a decline continues to occur in the price of clothing, which becomes Pc. This price decrease moves the expenditure budget line, which is the line c. The U3 curve is alluded to by line c in E2 indicating that the consumption of clothing has now increased to Q2.

In other words, the distribution of goods and services between consumers when after the allocation of goods between consumers results in a reduction of satisfaction for at least one person. Production will be efficient when any viable reallocation of intercompany input lowers the output level of at least one firm or a commodity. This means that the optimum pareto is a position where it is impossible to improve one's well-being. Pareto optimum indicates the criteria for making a welfare assessment. Pareto paid no attention to the distribution of income. According to this concept a framework of distribution or a reorganization of production and trade would be seen as an increase in welfare or decline in welfare, it would increase or worsen the position of at least one person without adversely affecting the other position.

The concept of pareto in optimum social welfare is the same as Baumol's concept of ideal output. Pareto requires three marginal conditions to explain the achievement of optimal situations in consumption, production and trade. The marginal conditions for overall optimization follow several important assumptions:

a. Each individual has an ordinal function and it is provided with a certain amount. On each product.

b. The production function in each company (manufacturer) is certain with the existing level of technology.

c. All items are very likely to be shared.

d. Each individual buys some of the goods.

e. All production factors are used in the production process of each good.

Pareto optimal overall can be derived as follows:

The first marginal condition ensures the optimum allocation of goods between consumers. This condition states that every consumer in the society, where the marginal rate of substitution between two goods must be the same. If the marginal substitution rate for two goods is not the same for two consumers, they can enter a trade that will increase the satisfaction of both or one without reducing the satisfaction (welfare) of the other. This is known as mutually profitable trade between two consumers. For an understanding of marginal conditions, look at the Edgeworth Box diagram in Figure 2.2 
(B)

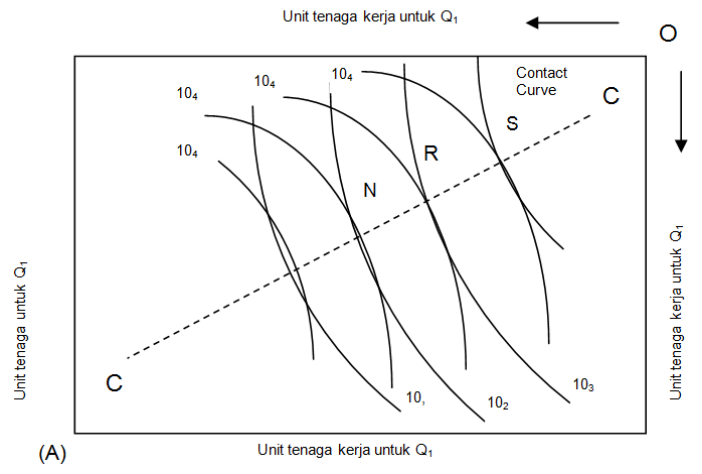

Figure 2.2. Edgeworth box

Pareto Optimal Condition In Figure 2.2 the vertical axis and the horizontal axis on the rectangular plane measures the quantities of Q1 and Q2 in fair trading. Each point in the box shows the distribution of goods between two consumers A and $\mathrm{B}$, the indifference maps of individuals $\mathrm{A}$ and $\mathrm{B}$ and their degree of satisfaction from the various combinations of Q1 and Q2 of the indifference map of $A$ are represented by using $O$ 'as the origin. In the case of two persons with two commodities, the trade balance will be achieved whereby the indifference curve of two consumers intersects with each other. In other words, the point of tangency of two kinds of indifference curves is the CC contract curve. Again we know that the slope of an indifference curve as the level of marginal substitution from Q1 to Q2.

The tangent point or trade balancing point of the indifference curve for two individuals is the same, the marginal rate of substitution of each is the same. Every point along the contract curve is optimal Pareto, any point outside the contract curve shows an optimum position because at a point a person will lose (in the sense that he remains on the same indifference curve Following the Pareto criterion, a movement from a known- optimum $\mathrm{R}$ to another point $\mathrm{M}$ or $\mathrm{N}$ within the $\mathrm{CC}$ contract curve will benefit someone without harming another.For example, if the original individual on $\mathrm{R}$ they can move to $\mathrm{M}$, where $\mathrm{B}$ will reach the higher indifference curve and A keep moving from a nonoptimum point to another point on the contract curve, social welfare becomes maximum.However, a movement along the contract curve in either direction can not make them better.A movement like this will always benefit an individual and harm another So that every point on the contract curve shows the Pareto social welfare.

Based on Pareto Optimal theory above can be concluded that one can get prosperity with an assumption of the welfare of another community member also decrease. With subsidies, overweight members of the community will allocate a portion of their income to a deficient member of society so that all members of the community can enjoy life as it should. The allocation of a part of the revenue of overweight members of society is a form of welfare reduction according to Pareto theory. If there is no decrease in this health, general welfare will not be achieved.

Hyman [6], Various forms of government programs have been established to assist the poor to raise the minimum standards of their lives. The reason that is often used by the government as the basis of the program because the market has led to the income of low-income families is not sufficient minimum needs for life. There are two kinds of programs for poor families; the first in-kind benefits are tangible goods or services provided to the recipient of the program so that the consumption of goods and services increased, the form can be health services, provision of food and so forth. This type of aid is also called fixed allotment subsidies, i.e. subsidies are given to parties who deserve to receive some goods in one period. The second form is cash assistance to the poor or assistance provided in cash to poor families.

\section{METHODOLOGY AND MODELLING}

The primary tool of this study is a questionnaire addressed to the respondents of families receiving rice for low-income families. Also, interviews with resource persons (government officials, community leaders, both formal and informal) will also be conducted. This technique is expected to strengthen the information gathered through the questionnaire. Measurement of research variables using instruments in the form of Likert scale 1-5 as follows: (1) very inadequate, (2) inadequate, (3) neutral, (4) adequate, (5) very appropriate. Then to categorize the average response respondent made interval scale calculated from the highest score minus the lowest score divided by five, obtained the range for category equal to 0,80 , Inferential Statistic Method used in this research data analysis is Structural Equation Modeling (SEM). The reason for using SEM, the consideration that the causal relationship formulated in this study uses a non-simplified model that doubles as a Rice subsidy. This form of the causal relation requires an analysis that can explain simultaneously. SEM as an extension or combination of several multivariate techniques. Ferdinand [7]. The structural equation model (SEM) is a collection of techniques that enable the testing of a relatively complex set of relationships simultaneously. Such complex relationships can be in the form of one or more dependent variables with one or more independent variables. Each construct is 
constructed from several indicator variables, The analyzer in Structural Equation Modeling (SEM) using AMOS software. The AMOS program demonstrates the measurement of structural problems and is used to test hypothetical models. This is due to the ability to estimate the known coefficients of fundamental linear equations, accommodating models that are latent variables, accommodating measurement errors on independent and dependent variables, providing simultaneous reciprocal alerts and interdependencies. Structural Equation Modeling's structural model allowed to estimate different regression equations but related to each other simultaneously. SEM also allows representing unobserved concepts in existing relationships and taking measurement errors into account. SEM is used to test the research hypothesis. Pattern relationship between variables to be studied is the causal relationship of one or several independent variables on one or more dependent variables.

\section{RESULTS}

The first alternative hypothesis in this study proved acceptable. This condition can be seen from the significant effect of Rice subsidy on the expenditure of low-income family consumption with the estimated coefficient of 1.055 at the level of significance less than 0.05 . This aim means that when Rice subsidy increases by one-unit, then the consumption of poor families in North Sumatra will increase by 1.055 one-unit. The significant effect of Rice subsidy on the consumer spending of lowincome families indicates that the consumer spending of poor households is affected by the subsidy of Rice subsidy. This condition is caused by subsidies given will have an impact on the increasing purchasing power of the poor. Increased purchasing power will lead to the consumption of the poor to rise. The subsidy of rice for the poor has resulted in a reduction in the number of low-income families' spending. Reduced monthly expenditure of lowincome families causes the allocation of income to change. Initially to buy rice, but subsidized rice means that the income that must be purchased to rice is now not bought into rice. From the author's observations and interviews, low-income families allocated their earnings to other than rice. Lowincome families allocate much of their income to secondary needs such as going out to eat and drinking outdoors, going on entertainment, and increasing consumption of food other than rice. With the subsidy of this Rice subsidy, the consumer spending of the low-income families on the rice goes down, but their consumption to other needs is increased.
The second alternative hypothesis in this study proved acceptable. This condition can be seen from the significant effect of Rice subsidy subsidy on lowincome family welfare with the estimated coefficient of 1,661 at the level of significance less than 0.05 . This finding means that when Rice subsidy increases by one-point, then the well-being of low-income families in North Sumatra will increase by 1,661 oneunit. The significant effect of Rice subsidy subsidy on the welfare of low-income families indicates that well-being of low-income families is affected by Rice subsidy. This is because Rice subsidy given by the government has been proven to increase the expenditure of low-income families to other needs. In other words, there has been a substitution of the needs of the core needs of rice into other needs. This situation encourages the increase of people's purchasing power to other requirements. The poor allocate their income to the needs that they have not been able to meet because of limited income. Because of this subsidy, the poor have allocated a portion of their opinions to meet other needs such as entertainment, going out to eat and drinking outdoors, buying clothes and so on.

From the above conditions, it can be said that the low-income families in North Sumatra Province can meet other needs that have rarely been met. The fulfillment of several other requirements has had an impact on the higher consumption of society. Increased use is one indicator of greater family welfare. Therefore, it can be said that Rice subsidy has an impact on improving the welfare of lowincome families.

The third alternative hypothesis in this study proved acceptable. This condition can be seen from the significant effect of Rice subsidy on consumption expenditure and low-income family welfare with the estimated coefficient of 0.672 at the level of significance less than 0.05 . This means that when Rice subsidy increases by one-unit, then the consumption and welfare expenditure of low-income families in North Sumatra will increase by 0.672 oneunit. The significant effect of Rice subsidy subsidy on consumer spending and well-being of poor households indicates that the consumption and wellbeing spending of poor households is influenced by Rice subsidy. As explained above, this condition is caused by the subsidy will cause the low-income families to enjoy income savings as much as the support given. These revenue savings have an impact on increasing power 


\section{CONCLUSIONS}

Based on the results of research and discussion in the previous chapter, this research can be summarized as follows:

1. Rice subsidy has a positive and significant impact on the consumption expenditure of lowincome families. This research can be seen from the probability value of Rice subsidy to low-income family consumer spending in North Sumatera Province which is small from $\alpha=0,05$.

2. Rice subsidy has a positive and significant impact on the welfare of low-income families. This can be seen from the probability value of Rice subsidy to low-income family health in North Sumatera Province which is small from $\alpha=0,05$.

3. Rice subsidy has a positive and significant impact on consumption expenditure and the welfare of low-income families. This can be seen from the probability value of Rice subsidy on consumer spending and low-income family welfare in North Sumatera Province which is small from $\alpha=0,05$.

The Government of Indonesia and the Provincial Government of North Sumatera Province must continue to maintain the rice subsidy program for the poor. Because this program has had a real impact on the increase in consumption expenditure of lowincome families and their welfare. It is known that this Rice subsidy subsidy program makes the health of poor people in North Sumatera Province increased by the increasing consumption of other goods needs.

\section{ACKNOWLEDGMENT}

Acknowledgments to the Rector of Panca Budi Development University, Institute for Research and Community Service UNPAB and DRPM Directorate General of Strengthening of Risbang, which has provided trust and financing support and facilitated the process of receiving research grants Doctoral Dissertation.

\section{REFERENCES}

[1] Tabor, Steven R dan M Husein Sawit (2006) Program Bantuan Natura dan OPK : Penilaian Makro. Jakarta : Pusat Penelitian dan PEngembangan Perum Bulog.

[2] Anak Bangsa Peduli (2006) Laporan Monitoring dan Evaluasi Program Raskin Kota Cimahi dan Kabupaten Garut, Bandung : LSM ABP.

[3] LP3ES (2000) Studi Evaluasi JPS-OPK Beras di Daerah Peddesaan Tahun Anggaran 1999/2000. Jakarta : LP3ES

[4] Joseph E. Stiglitz, (2011), Mengukur Kesejahteraan. Mutiara Arumsari.

[5] Pindyck, Robert S. dan Daniel L. Rubinfeld. (2003). Mikroekonomi. (Aldi Jenie. Terjemahan). Jakarta : PT.Indeks. Buku asli diterbitkan tahun 2001.
[6] Hyman, (2006), The Economic Analysis of Government and Related Themes.

[7] Ferdinand, Augusty. 2000. 'Structural Equation ModelingDalam Penelitian Manajemen'. Badan Penerbit Universitas Diponogoro. 